\title{
Three new species of Marsdenia (Apocynaceade) from Brazil
}

\section{Fabio da Silva do Espírito Santo ${ }^{1 *}$, Amanda Pricilla Batista Santos ${ }^{1}$, Patrícia Luz Ribeiro ${ }^{1,2}$ and Alessandro Rapini}

Received: November 11, 2017

Accepted: December 13, 2017

\begin{abstract}
Three new species of Marsdenia (Apocynaceae) are described from Brazil: M. paganuccii, known from two disjunct populations, one in the Caatinga of Bahia and other in the Atlantic Forest of Espírito Santo; M. paraibana, restricted to the Restinga of Cabedelo National Forest in the Atlantic Forest of Paraíba; and M. trisegmentata, known from two populations in Caatinga, one in Bahia and other in Ceará. Illustrations, a geographic distribution map and comparisons with morphologically similar species are also presented for each species.
\end{abstract}

Keywords: Apocynaceae, Asclepiadoideae, Atlantic Forest, Brazil, Caatinga, conservation, Marsdenia, Neotropics, taxonomy, threatened species

\section{Introduction}

Marsdenia (Apocynaceae: Asclepiadoideae) comprises approximately 200 species, mainly from tropical and subtropical regions (Liede \& Albers 1994; Endress \& Bruyns 2000; Stevens 2009), is one of the largest genus of Marsdenieae and the only genus of the tribe in the Neotropics. It comprises a great morphological variation and is easily distinguished from the other genera of asclepiads in the New World by the erect pollinia, attached to the caudicles at the base. In Brazil, Marsdenia is represented by 34 species (Flora do Brasil 2020) and is the fourth asclepiad genus in number of species (Rapini 2012), occurring in different types of vegetation, from the Amazonian and Atlantic rain forests to the Caatinga seasonally dry forests. During the preparation of the treatment of Marsdenia from Brazil, we recognized three new species of the genus, which are described below as $M$. paganuccii, $M$. paraibana and M. trisegmentata.

Preliminary phylogenetic analyses using molecular data has shown that Marsdenia s. l., as traditionally circumscribed, is not monophyletic and the American species of the genus are not closely related to the Asian $M$. tinctoria R.Br., the type of Marsdenia (Livshutz et al. 2016; FS Espírito Santo unpubl. res.). To become monophyletic Marsdenia should comprise almost all other genera of the tribe or become reduced to only a few species closely related to $M$. tinctoria. A broader circumscription will require the synonymyzation of other genera, such as Gymnema R.Br., with 25 species, but probably also the more traditional Dischidia R.Br. and Hoya R.Br., with approximately 80 and 350 species, respectively, under Marsdenia. A narrower circumscription will require the segregation of the American species and the reinstatement of Ruehssia H.Karst. (see Rapini et al. 2001, for names available to this group under the synonymy of Marsdenia). Since Marsdenia is the only genus of Marsdeniae currently accepted in the New World, we are describing the three new species in it, predicting their transference to Ruhessia in a near future, as a recircumscription of Marsdenia is inevitable and then a reduced concept of the genus is more likely.

\section{Taxonomy treatment}

Marsdenia paganuccii F.Esp.Santo \& A.P.B.Santos sp. nov. Type: BRAZIL. BAHIA: Iaçu, fazenda Santo Antônio,

\footnotetext{
1 Programa de Pós-graduação em Botânica, Departamento de Ciências Biológicas, Universidade Estadual de Feira de Santana, 44036-900, Feira de Santana, BA, Brazil

2 Centro de Ciências Agrárias, Ambientais e Biológicas, Universidade Federal do Recôncavo da Bahia, 44380-000, Cruz das Almas, BA, Brazil

* Corresponding author: fse.santo@yahoo.com.br
} 
BA-046 (Milagres-Iaçu), 1248'25”S 4005'51'”, 28/ XII/2014, fl., F.S. Espírito Santo et al. 200 (Holotype: HUEFS; Isotypes: $\mathrm{K}, \mathrm{NY}, \mathrm{RB}, \mathrm{SPF}$ ).

Figs. 1A-F, 2A-C, 3.

Marsdenia paganuccii differs from all other Neotropical species of the genus by the combination of (sub)sessile, dense inflorescences, with few (up to 6) (sub)sessile, tiny flowers ( $<2.5 \mathrm{~mm}$ long), corolla rotate, vinaceous, adaxially pubescent, and corona lobes subdeltate to ovate, puberulent at the base.

Vine. Stems glabrous, pubescent while young. Leaves opposite, without colleters; petiole $0.3-1.0 \mathrm{~cm}$ long, pubescent; lamina $3.0-8.3 \times 1.1-3.25 \mathrm{~cm}$, elliptic to subovate, glabrous or pubescent abaxially, sparsely pubescent adaxially, base attenuate, apex cuspidate or rarely acute, margins revolute. Inflorescences dense, 3-6-flowered, sessile to subsessile (peduncle $<2 \mathrm{~mm}$ long); bracts $0.46-0.51 \times$ 0.35-0.44 mm, ovate, margins ciliate. Flowers sessile to subsessile (pedicel < $1.3 \mathrm{~mm}$ long); sepals 1.3-1.7 $\times$ 0.6-1.0 mm, ovate to elliptic, apex cuneate, pubescent, margins ciliate, adaxially with 5 alternisepalous colleters; corolla rotate, vinaceous, abaxially glabrescent, adaxially pubescent, tube c. $0.8 \times 1.5 \mathrm{~mm}$, lobes $1.4-1.8 \times 1.1-1.5$ $\mathrm{mm}$, ovate, patent to recurved, apex cuneate, margins not ciliate; corona lobes $5,0.53-1.1 \times 0.52-0.76 \mathrm{~mm}$, subdeltate to ovate, puberulent at the base, apex acute, as high as or slightly higher than the style-head; anthers c. $0.23 \times 0.14$ $\mathrm{mm}$, apical membranous appendix 0.39-0.44 × 0.31-0.35 $\mathrm{mm}$, transversely elliptic, lower than the style-head apex; corpuscullum $0.17-0.24 \times 0.03-0.05 \mathrm{~mm}$, narrowly oblong, apex obtuse, caudicles $0.04-0.1 \mathrm{~mm}$ long, distally plicate, pollinia $0.2-0.24 \times 0.09-0.11 \mathrm{~mm}$, obovoid; gynostegium shortly stipitate (stipe c. $0.35 \mathrm{~mm}$ tall), style-head c. $0.25 \times$ $0.85 \mathrm{~mm}$, capitate, exserted from the corolla tube. Fruits and seeds unknown.

Specimens examined (paratypes): BRAZIL. Bahia: Iaçu, fazenda Santo Antônio, BA-046 (Milagres-Iaçu), $12^{\circ} 48^{\prime} 25^{\prime \prime}$ S 4005'51'W, 270 m, 13/XI/2016, fl., A. Rapini 2080 (HUEFS); ibidem, 29/III/2017, fl., F.S. Espírito Santo \& D.J.L. Sousa 232 (HUEFS); Espírito Santo: Fazenda de Santa Adelaide, 5/XII/1943, fl., J.G Kuhlmann 6624 (HUEFS, RB).

Distribution and habitat: Marsdenia paganuccii is known only from two disjunct populations, one in Iaçu, state of Bahia, and other in the state of Espírito Santo (unknown municipality) (Fig. 3), both on rocky outcrops. In Bahia, it occurs in the Caatinga domain, in a vegetation formed mainly by sparse shrubs and small trees, on a thicket of Euphorbia sp. (Euphorbiaceae). In Espírito Santo, its occurrence is uncertain; the only reference in the label is "Rio Doce, Fazenda de Santa Adelaide", without information about the vegetation or environment. Since the whole state of Espírito Santo is within the Atlantic Forest domain, this is the only ecological information available for this population.

Conservation status: Despite exhaustive field work, only two specimens of Marsdenia paganuccii have been found at the location in Bahia, both on rocky outcrops surrounded by pasture, about $60 \mathrm{~m}$ distant from a busy vicinal road and $700 \mathrm{~m}$ from the BA-046 state highway. The specimen from Espírito Santo was collected more than 70 years ago and lacks information about population density and environmental conditions. The increase in anthropogenic disturbance in the Rio Doce basin, mainly caused by deforestation, disorderly occupation, mining and, more recently, the dam collapse in Mariana (Minas Gerais), and the lack of recent collections from Espírito Santo suggest that M. paganuccii is probably extinct in this state. Based on its small area of occupancy $\left(\mathrm{AOO}=\mathrm{c} .4 .5 \mathrm{~km}^{2}\right.$, estimated from the polygon area in Google Earth Pro), restricted to one (or two) locations, and the small population observed in Bahia, with only two specimens occurring in a highly disturbed area, $M$. paganucci should be treated as Critically Endangered [CR B2ab(i, ii, iii, iv); D], according to the IUCN's (2016) criteria.

Etymology: The epithet honors the Professor Dr. Luciano Paganucci de Queiroz, who has greatly contributed to the knowledge and conservation of the Brazilian flora, especially of the seasonally dry forests.

Phenology: The species was collected with flowers in November, December and March.

Notes: Marsdenia paganuccii is characterized by dense inflorescences, sessile to subsessile, with few flowers, which are also sessile or subsessile, corolla vinaceous, rotate, adaxially pubescent, with a small tube $($ c. $0.8 \times 1.5 \mathrm{~mm})$, gynostegium short-stipitate, exserted from the corolla tube, corona lobes subdeltate to ovate, puberulent at the base and acute at the apex. Marsdenia paganuccii can be related to M. pickelii Fontella \& Morillo because of their dense inflorescences, but is easily distinguished from it by the corolla rotate ( $v s$. campanulate), vinaceous ( $v s$. yellowish-cream), with a smaller tube (c. $0.8 \times 1.5 \mathrm{~mm} v s$. > $1.4 \times 2.4 \mathrm{~mm}$ ) and lobes adaxially pubescent (vs. glabrous), corona lobes up to $1.1 \mathrm{~mm}$ long (vs. $>2.0 \mathrm{~mm}$ ), subdeltate to ovate, not auriculate ( $v s$. with a lower portion auriculate and invaginated and an upper portion ovate), and smaller pollinia ( $\leq 0.24 \mathrm{~mm} v s$. $>0.39 \mathrm{~mm}$ long).

Marsdenia paraibana F.Esp.Santo \& A.P.B.Santos sp. nov. Type: BRAZIL. PARAÍBA: Cabedelo, Mata da Amem, 31/I/2000, fl., A.J. Pontes \& J.R. Lima 400 (Holotype: JPB).

Figs. 1G-L, 3.

Marsdenia paraibana is morphologically related to $M$. hilariana var. macieliana Fontella \& R.J. Paixão, differing by the leaves with lamina acuminate at the apex (vs. mucronate or cuspidate) and tertiary veins conspicuous (vs. inconspicuous), smaller sepals $(<3.2 \times 2.2 \mathrm{~mm} v s$. > $4.1 \times 3.9 \mathrm{~mm}$ ), corolla brownish (vs. purplish), with lobes elliptic to obovate (vs. oblong to widely elliptic), corona lobes $\wedge$-shape, acute at the apex (vs. triangular, rounded at the apex), and caudicles distally plicate (vs. not plicate).

Vine. Stems glabrous, nodes with yellowish peeling. Leaves opposite, adaxially with c. 5 colleters at the base of the main vein; petiole $0.9-1.0 \mathrm{~cm}$ long, glabrous; lamina 


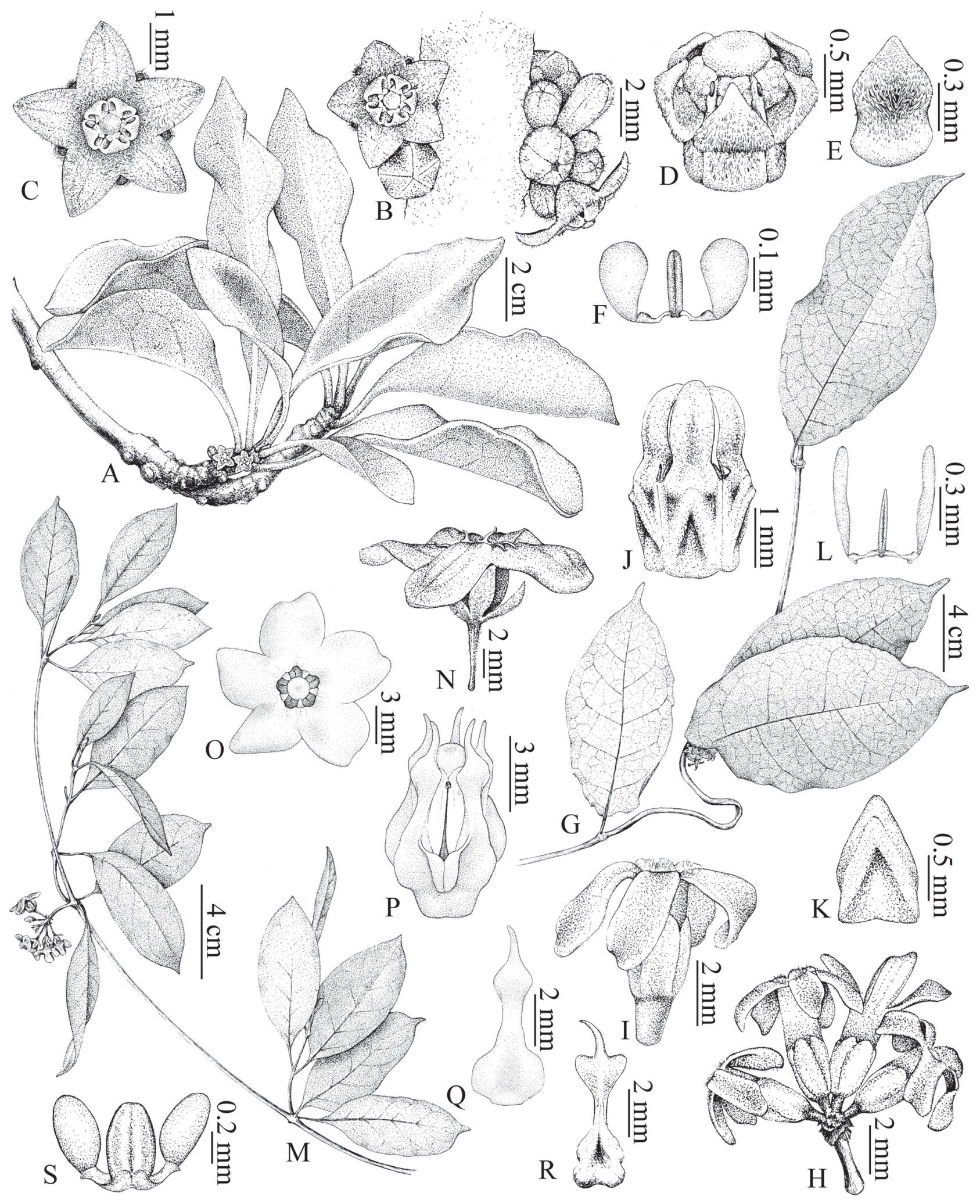

Figure 1. A-F. Marsdenia paganuccii. A. Branch with leaves and inflorescence; B. Branch with inflorescence; C. Flower, seen from above; D. Flower, perianth removed to show the corona in front of gynostegium; E. Corona lobe, frontal view; F. Pollinarium. G-L. $M$. paraibana. G. Branch with leaves and inflorescence; H. Inflorescence; I. Flower, lateral view; J. Flower, perianth removed to show the corona and anther wings in front of gynostegium; K. Corona lobes, frontal view; L. Pollinarium. M-S. M. trisegmentata: M. Branch with leaves and inflorescence; N. Flower, lateral view; $\mathbf{O}$. Flower, seen from above; P. Flower, perianth removed to show the corona in front of gynostegium; Q-R. Corona lobe, frontal view; S. Pollinarium (Illustrated by Gustavo Surlo from the holotypes). 

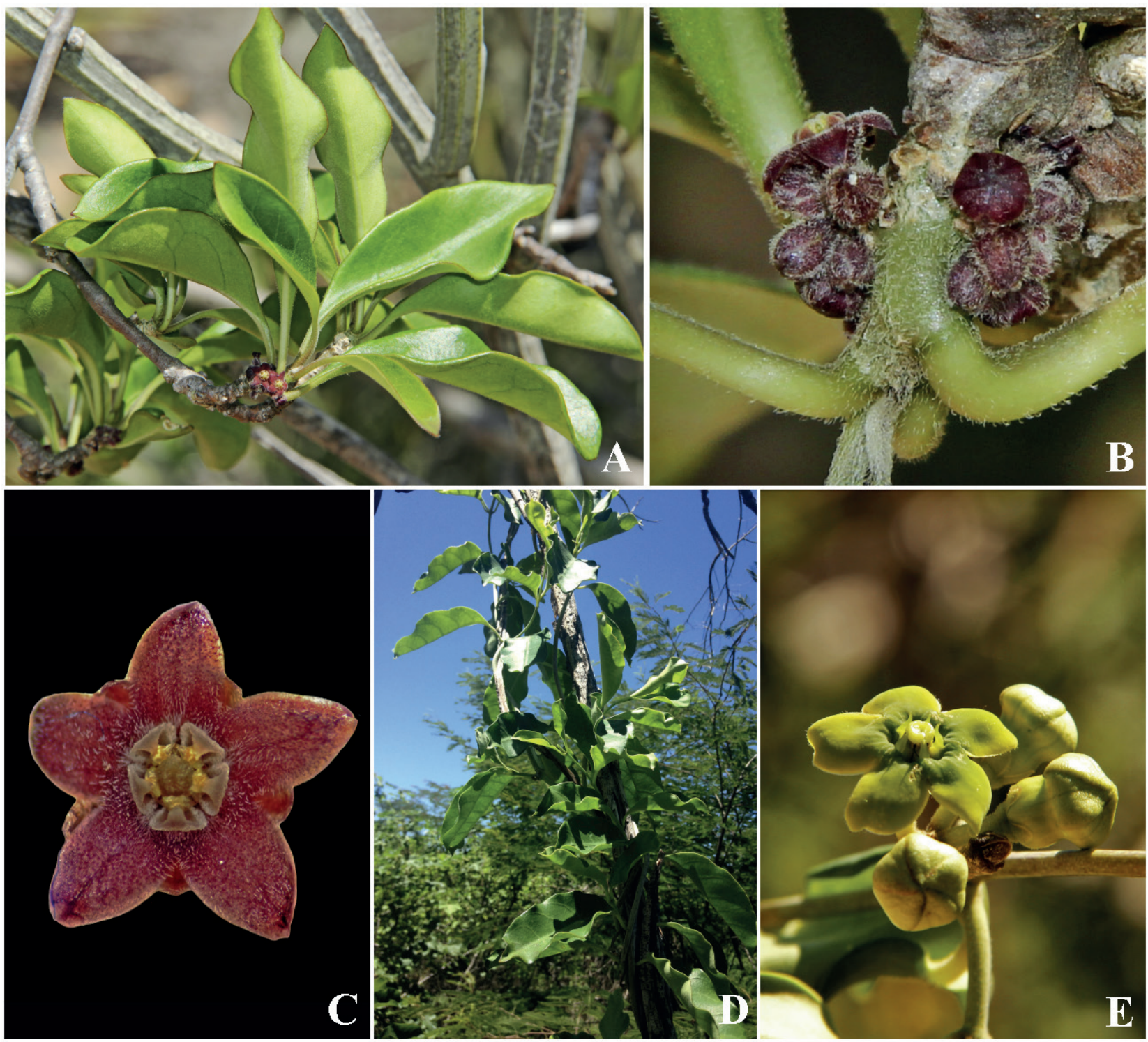

Figure 2. A-C. Marsdenia paganuccii. A. Branch with leaves and inflorescence; B. Branch with inflorescences; C. Flower, seen from above. D-E. M. trisegmentata. D. Branch with leaves; E. Inflorescence (Photos by F.S. Espírito Santo).

11.6-14 × 5.1-7.35 cm, elliptic, glabrous, base obtuse, apex acuminate, margins revolute, tertiary veins conspicuous on both faces. Inflorescences umbelliform, 5- or 6-flowered; peduncle 2.8-3.5 mm long, glabrous; bracts c. $0.8 \times 1.0$ $\mathrm{mm}$, ovate, margins ciliate. Flowers with pedicel 1.5-2.0 mm long, glabrous; sepals 2.9-3.1 × 1.8-2.1 mm, elliptic to ovate, apex obtuse, margins ciliate, glabrous, adaxially with 5 alternisepalous colleters; corolla urceolate, brownish, abaxially glabrous, adaxially with five lines of trichomes, villose along the fauce, tube $3.5-3.9 \times 1.8-2.5 \mathrm{~mm}$, lobes $3.8-4.5 \times 1.7-2.3 \mathrm{~mm}$, elliptic to obovate, recurved, glabrous, apex obtuse, irregularly emarginate, margins ciliate; corona lobes $5,1.25-1.5 \times 0.48-0.6 \mathrm{~mm}$, 'inverted V-shape' $(\wedge)$, adnate to the anther dorsum, below the thecae; anthers c. $0.9 \times 0.16 \mathrm{~mm}$, apical membranous appendix $1.8-1.9 \times$
0.7-0.8 $\mathrm{mm}$, cochleariform, surpassing the style-head; corpuscullum $0.45-0.48 \times$ c. $0.05 \mathrm{~mm}$, lanceolate, apex acute, recurved, caudicles $0.15-0.2 \mathrm{~mm}$ long, distally plicate, pollinia $0.75-0.8 \times$ c. $0.13 \mathrm{~mm}$, oblong to oblong-obovoid; gynostegium sessile, style-head c. $0.8 \times 0.8 \mathrm{~mm}$, subconic, bilobed, within or slightly exserted from the corolla tube. Fruits and seeds unknown.

Distribution and habitat: The species is known only by the holotype, collected at the Restinga of Cabedelo National Forest, in a locality known as 'Mata da Amem'. This National Forest has 103.36 hectares and holds one of the last fragments of Atlantic Forest in the state of Paraíba (Brasil 2004).

Conservation status: The Restinga of Cabedelo National Forest is an environmental conservation unit established in 2004 at the João Pessoa metropolitan region. The region 


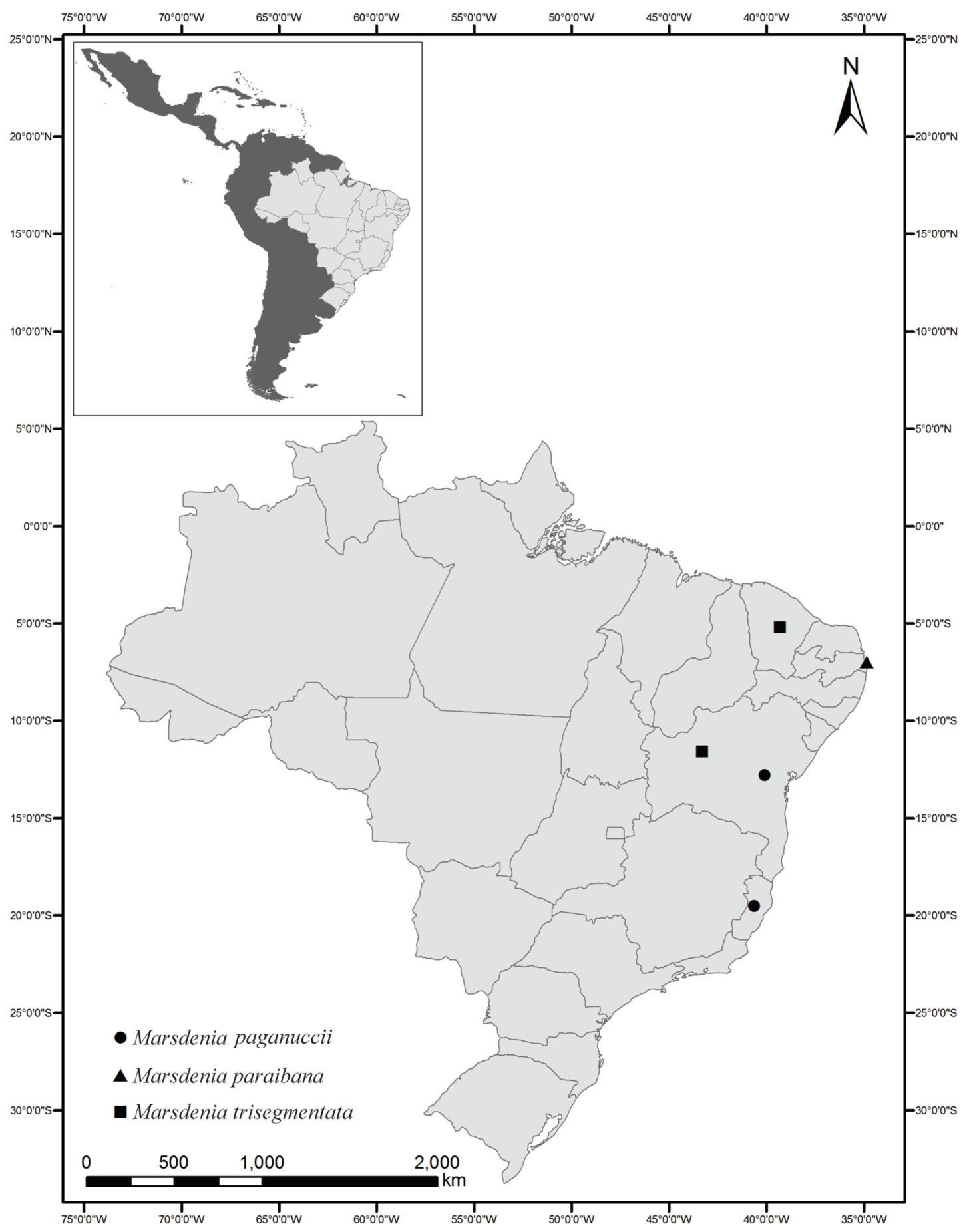

Figure 3. Distribution map of Marsdenia paganuccii, M. paraibana and M. trisegmentata.

has the highest Gross Domestic Product of the state of Paraíba (IDEME 2016) and the conservation unit is the first in an urban area in Brazil (Brasil 2004). Although legally protected, Marsdenia paraibana is restricted to a small isolated fragment $\left(\mathrm{AOO}=\right.$ c. $0.5 \mathrm{~km}^{2}$, estimated from the polygon area in Google Earth Pro) of well-preserved vegetation, known as Mata da Amem (Associação Metropolitana para a Erradicação da Mendicância), which corresponds to approximately only one third of the National Forest area (c. $1.6 \mathrm{~km}^{2}$ ), and is under strong anthropogenic pressure and socioenvironmental conflicts (Andrade et al. 2014). The small area of occupancy and size of population, which is restricted to a single fragment of vegetation within the capital of Paraíba, are reasons to consider this species 
Critically Endangered, according to the IUCN's (2016) criteria [CR B2ab(ii, iii); D].

Etymology: The epithet refers to the state of Paraíba, where M. paraibana occurs.

Phenology: The species was collected with flowers in January.

Notes: Marsdenia paraibana is characterized by the elliptic leaves, with acuminate apex and conspicuous tertiary veins in both faces, inflorescences with few flowers and a small peduncle, flowers shortly pedicellate, with elliptic to ovate sepals, urceolate brownish corolla, with elliptic to obovate long lobes, corona lobes in upside down $\mathrm{V}$-shape ( $\wedge$-shape), acute at the apex, the apical appendix of anthers cochleariform, surpassing the style-head, and caudicles distally plicate. It is morphologically similar to M. hilariana var. macieliana, but can be distinguished from it by the characters in the diagnosis. Marsdenia paraibana can also be related to $M$. amorimii Morillo and $M$. dorothyae Fontella \& Morillo, both endemic to the Atlantic Forest, differing from them, among other characters, by the unique shape of the corona lobes, which are oblong-ovate in M. amorimii and ovate in M. dorothyae.

Marsdenia trisegmentata F.Esp.Santo \& A.P.B.Santos sp. nov. Type: BRAZIL. BAHIA: Morpará, $11^{\circ} 35^{\prime} 50^{\prime \prime} \mathrm{S}$ $43^{\circ} 17^{\prime} 04^{\prime \prime} W, 28 / X I / 2016$ (fl.), F.S. Espírito Santo et al. 231 (Holotype: HUEFS; Isotypes: K, NY, RB).

Figs. 1M-S, 2D-E, 3.

Marsdenia trisegmentata is distinguished from all other Neotropical species of the genus by the combination of corolla widely campanulate, green to yellowish-green, with large lobes $(\geq 6.3 \times 3.6 \mathrm{~mm}$ ), oblong to widely ovate, patent, and large corona lobes (6.7-7.6 mm long), trisegmented, with a lower portion suborbicular, concave or triangular invaginated, a middle portion rhomboid or triangular and an apical portion narrowly triangular, falcate.

Vine. Stems glabrous, pubescent while young. Leaves opposite, adaxially with 2-4 colleters at the base of the main vein; petiole $0.5-2.2 \mathrm{~cm}$ long, pubescent or with sparse trichomes; lamina $2.8-9.0 \times 1.4-4.0 \mathrm{~cm}$, elliptic or subovate, glabrous or sparsely pubescent on both faces, base cuneate, apex acuminate, cuspidate or acute, margins revolute. Inflorescences umbelliform, 2-7-flowered; peduncle $0.65-1.4 \mathrm{~cm}$ long., sparsely pubescent; bracts $0.7-2.5 \times 0.3-0.85 \mathrm{~mm}$, deltate, margins ciliate. Flowers with pedicel $4.0-9.0 \mathrm{~mm}$ long, pubescent; sepals 3.0-5.0 $\times$ 1.9-2.2 mm, elliptic to ovate, apex cuneate, margins ciliate, sparsely pubescent, adaxially with 5 alternisepalous colleters; corolla widely campanulate, green to yellowishgreen, glabrous or occasionally with short sparse trichomes adaxially, tube $4.5-5.8 \times 4.6-6.4 \mathrm{~mm}$, lobes $6.3-8.0 \times$ 3.6-6.7 mm, oblong or widely ovate, patent, apex rounded to irregularly emarginate, margins ciliate; corona lobes 5 , $6.7-7.6 \times 1.8-2.3 \mathrm{~mm}$, a lower portion suborbicular and concave or triangular and invaginated, a middle portion rhomboid or triangular and an apical portion narrowly triangular, falcate, surpassing the style-head; anthers c. $0.45 \times 0.26 \mathrm{~mm}$, apical membranous appendix $0.65-0.8 \times$ 0.9-1.3 mm, transversally elliptic to subrectangular, below the style-head apex; corpuscullum $0.40-0.44 \times 0.24-0.28$ $\mathrm{mm}$, ovoid to oblong, apex rounded, caudicles $0.24-0.27$ $\mathrm{mm}$ long, pollinia $0.46-0.51 \times 0.25-0.34 \mathrm{~mm}$, ellipsoid; gynostegium stipitate (stipe c. $1 \mathrm{~mm}$ tall), slightly exserted from the corolla tube, style-head c. $1.5 \times 2.0 \mathrm{~mm}$ long. Fruits unknown.

Specimens examined (paratypes): BRAZIL. Bahia:

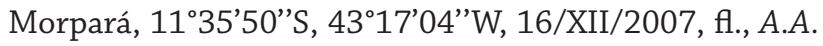
Conceição et al. 2645 (HUEFS); Ceará: Quixeramobim (cultivated at Jardim de Plantas Tóxicas do Hospital Veterinário da Universidade Federal de Campina Grande, Campus Patos, Paraíba), 2009, fl., F. Riet-Correa s. (HUEFS 236014).

Distribution and habitat: Marsdenia trisegmentata is known only from two populations in the Caatinga domain, one in Morpará, state of Bahia, and other in Quixeramobim, state of Ceará (Fig. 3). In Morpará, it occurs in the São Francisco valley, in a seasonally dry vegetation constituted mainly of shrubs and trees, and is found at the apex of branches up to $2.5 \mathrm{~m}$ tall. Its occurrence in Quixeramobim is determined based on isolated flowers from a plant cultivated at the Garden of Toxic Plants at the Veterinary Hospital of the Federal University of Campina Grande, Patos campus, state of Paraíba.

Conservation status: In Bahia, M. trisegmentata is restricted to a fragment of vegetation under anthropogenic pressure, which is common in the whole region of the São Francisco valley. Due to agricultural activities and extensive breeding of goats and cattle, most vegetation in the Caatinga have been disturbed or changed. This population of $M$. trisegmentata is on the margin of a vicinal road, about 4 $\mathrm{km}$ distant from downtown, and therefore, also under the impact of urban expansion and car traffic. Although this population in Bahia is probably threatened, we have no data about the population of $M$. trisegmentata in Ceará. Therefore, we consider the Data Deficient (DD) to assess the conservation status of this species according to the IUCN's (2016) criteria.

Etymology: The epithet emphasises the unique trisegmentate shape of corona lobes.

Phenology: The species was collected with flowers in November and December.

Notes: Like other species of the genus, Marsdenia trisegmentata is also toxic to livestock and is popularly known as "mata-calado" (silent killer; as "Marsdenia aff. zehntneri" in Pessoa et al. 2011). It is characterized by the fleshy leaves, inflorescences with few flowers, corolla widely campanulate, green to yellowish-green, with lobes patent, larger than the tube, and corona lobes long (> $6.5 \mathrm{~mm}$ long), trisegmentate, formed by a lower portion suborbicular and concave or triangular and invaginated, a middle portion 
rhomboid or triangular and an apical portion narrowly triangular, falcate, surpassing the style-head and the corolla fauce. This combination of features is found exclusively in $M$. trisegmentata, distinguishing it from any other Neotropical species of Marsdenia.

\section{Acknowledgements}

This study is part of the first author's Ph.D. thesis, developed at PPGBot-UEFS with a CNPq fellowship and supported by the projects Reflora (CAPES and CNPq) and Universal (CNPq no. 485468/2013-1). We thank Cássia Bitencourt for preparing the map and two anonymous reviewers for improving the manuscript. $A R$ is a $C N P q$ researcher $(\mathrm{Pq}-1 \mathrm{D})$.

\section{References}

Andrade TM, Ramos RN, Silva PMU. 2014. Estudo da resiliência socioecológica em unidades de conservação: o caso da Floresta Nacional da Restinga de Cabedelo - PB. In: V Congresso Brasileiro de Gestão Ambiental, Belo Horizonte.

Brasil. 2004. Decreto s/nº de 02 de junho de 2004. Cria a Floresta Nacional da Restinga de Cabedelo, no Município de Cabedelo, no Estado da Paraíba, e dá outras providências. Diário Oficial, Brasília, DF, 03 jun. 2004. p. 5.
Endress ME, Bruyns PV. 2000. A revised classification of Apocynaceae s.l. The Botanical Review 66: 1-56.

Flora do Brasil. 2020 under construction. Marsdenia. Rio de Janeiro, Jardim Botânico do Rio de Janeiro. http://floradobrasil.jbrj.gov.br/ reflora/floradobrasil/FB4681. 19 Dec. 2017.

IDEME - Instituto de Desenvolvimento Municipal e Estadual. 2016. Produto Interno Bruto do estado da Paraíba e de seus municípios 2010-2013. João Pessoa, IDEME.

IUCN. 2016. Guidelines for using the IUCN red list categories and criteria. Version 12. Standards and Petitions Subcommittee. http://www. iucnredlist.org/documents/RedListGuidelines.pdf. 10 July 2016.

Liede S, Albers F. 1994. Tribal disposition of genera in the Asclepiadaceae. Taxon 43: 201-231.

Livshutz T, Liede-Schumann S, Meve U, Wanntorp L, Forster P. 2016. Phylogeny of Marsdenieae (Apocynaceae, Asclepiadoideae) and the cirscumscription of Marsdenia R.Br. based on chloroplast and nuclear loci. In: 23rd Symposium on Biodiversity and Evolutionary Biology of the German Botanical Society. Munich, Ludwig-MaximiliansUniversität München.

Pessoa CRM, Riet-Correa F, Medeiros RMT, Simões SVD, Rapini A. 2011. Poisoning by Marsdenia hilariana and Marsdenia megalantha (Apocynaceae) in ruminants. Toxicon 58: 610-613.

Rapini A, Mello-Silva R, Kawasaki ML. 2001 Asclepiadoideae (Apocynaceae) da Cadeia do Espinhaço de Minas Gerais, Brasil. Boletim de Botânica da Universidade de São Paulo 19: 55-169.

Rapini A. 2012. Taxonomy "under construction": advances in the systematics of Apocynaceae, with emphasis on the Brazilian Asclepiadoideae. Rodriguésia 63: 75-88.

Stevens WD. 2009. Marsdenia. In: Davidse G, Sousa M, Knapp S, Chiang F. (eds.) Flora Mesoamericana. Vol. 4, part 1. St. Louis, The Missouri Botanical Garden. p. 733-741. 